\title{
PENINGKATKAN PRESTASI BELAJAR KIMIA MELAUI PENERAPAN KOMBINASI METODE DISKUSI KELOMPOK DAN PENUGASAN TERSTRUKTUR
}

\author{
SUDIARTI \\ MAN 2 Sragen \\ Email : sudiarti69@gmail.com
}

\begin{abstract}
ABSTRAK
Penelitian ini bertujuan untuk meningkatkan prestasi belajar kimia siswa kelas X IPA 3 MAN 2 Sragen dalam memahami materi Reaksi Reduksi Oksidasi dan Tata Nama Senyawa melalui penerapan Kombinasi Metode Diskusi Kelompok dan Penugasan Terstruktur. Hasil penelitian ini mendiskripsikan proses dan hasil penerapan Kombinasi Metode Diskusi dan Penugasan Terstruktur. Hasil analisis menunjukkan bahwa penerapan Kombinasi Metode Diskusi dan Penugasan Terstruktur dapat meningkatkan hasil belajar peserta didik kelas X IPA 3 MAN 2 Sragen dalam materi Reaksi Reduksi oksidai dan Tata nama Senyawa. Secara kuantitatif terjadi peningkatan hasil belajar dari siklus I sebesar 69,25 dengan ketuntasan klasikal sebesar $65 \%$ ke siklus II sebesar 77,50 dengan ketuntasan klasikal sebesar 87,5\%. Hasil ini menunjukkan terjadinya peningkatan pemahaman peserta didik terhadap materi Reaksi Reduksi oksidasi dan Tata nama Senyawa sebesar 22,5\%. Secara kualitatif kemampuan peserta didik dalam memahami materi Reaksi Reduksi Oksidasi dan tata nama Senyawa meningkat dari kualifikasi sedang ke tinggi. Dengan demikian, Penerapan Kombinasi Metode Diskusi Kelompok dan Penugasan Terstruktur dapat meningkatkan pemahaman peserta didik terhadap memahami materi Reaksi Reduksi Oksidasi dan Tata nama Senyawa peserta didik kelas X IPA 3 MAN 2 Sragen Tahun Pelajaran 2017/2018
\end{abstract}

Kata Kunci: metode diskusi kelompok, metode penugasan terstruktur, prestasi belajar

\section{PENDAHULUAN}

Menurut kurikulum 2013 pembelajaran yang dilakukan mendorong aktivitas fisik dan mental siswa secara optimal. Pelaksanaan pembelajaran ini mendukung tumbuhnya pembelajaran aktif (active learning). Pembelajaran ini menggerakkan seluruh aktivitas fisik dan mental siswa sehingga siswa memperoleh banyak pengalaman belajar melalui pemberdayaan potensi dirinya. Michel Prince (2004) dalam kemendikbud (2017) mendefinisikan pembelajaran aktif sebagai proses belajar yang melibatkan siswa dalam proses pembelajaran. Pembelajaran aktif menuntut siswa melakukan kegiatan belajar bermakna dan berfikir tentang apa yang mereka lakukan. Definisi ini dapat mencakup kegiatan, seperti pekerjaan rumah, kegiatan di kelas, maupun kegiatan di masyarakat. Inti pembelajaran aktif adalah aktivitas siswa dan keterlibatannya dalam proses pembelajaran.

Permasalahan yang terjadi di MAN 2 Sragen adalah pembelajaran masih belum aktif dan efektif. Metode yang digunakan oleh guru belum sepenuhnya membuat siswa aktif dalam pembelajaran di kelas. Fakta menunjukkan bahwa guru masih mengalami kesulitan dalam memahami dan mengimplementasikan pembelajaran yang mampu mengaktifkan potensi siswa secara optimal (pembelajaran berbasis pemberdayaan potensi). Untuk mebuat pembelajaran aktif dan peningkatan pemahaman materi bagi siswa peneliti menggunakan kombinasi metode diskusi kelompok dengan penugasan terstruktur. Metode ini diharapkan dapat meningkatkan motivasi belajar dan meningkatkan keaktifan siswa dalam pembelajaran. Menurut Vygotsky pembelajaran terjadi apabila anak bekerja atau belajar menangani tugas-tugas yang belum dipelajari namun tugas-tugas itu masih berada dalam jangkauan kemampuannya (Slavin dalam Depdiknas 2005). Implikasi teori Vygotsky dalam pembelajaran sains dalam kelas adalah pembelajaran kooperatif antar siswa (Depdiknas 2005). Salah satu bentuk pembelajaran kooperatif adalah diskusi kelompok. Diskusi adalah aktivitas dari sekelompok siswa, berbicara saling bertukar informasi maupun pendapat tentang sebuah topik atau masalah, dimana setiap 
anak ingin mencari jawaban/penyelesaian problem dari segala segi dan kemungkinan yang ada (Depdikbud:1994). Metode diskusi adalah cara penyajian pembelajaran, di mana siswa-siswa dihadapkan kepada suatu masalah, yang bisa berupa pernyataan atau pertanyaan yang bersifat problematis untuk dibahas dan dipecahkan bersama (Djamarah:2006). Sedangkan menurut Djajadisastra (1983) metode diskusi atau diskusi kelompok adalah format belajar mengajar yang menitik beratkan kepada interaksi antara anggota yang lain dalam suatu kelompok guna menyelesaikan tugas belajar secara bersama. Diskusi kelompok juga didefinisikan pembahasan suatu topic dengan cara tukar pikiran antara dua orang atau lebih, dalam kelompok-kelompok kecil, yang direncanakan untuk mencapai tujuan tertentu (Devi:2016).

Hamalik, (1994) tugas dapat menumbuhkan rasa tanggung jawab bagi siswa sehingga akan mendorong siswa untuk lebih semangat untuk belajar. Dimyati (1993) menyatakan bahwa pemberian tugas dapat diartikan sebagai format interaksi belajar mengajar yang ditandai adanya satu atau lebih tugas yang diberikan oleh guru, dimana penyelesain tugas tersebut dapat dilakukan secara perorangan atau secara kelompok sesuai perintahnya. Pemberian tugas merupakan alat yang berguna untuk menjabarkan suatu tujuan yang akan dicapai yang dapat diberikan kepada siswa secara terencana atau terstruktur yang memuat tujuan pelajaran yang jelas, petunjuk pengerjaan dan diberikan secara teratur setiap satuan topik atau setiap unit pelajaran. Pemberian tugas terstruktur dimaksudkan untuk tindak lanjut tingkat pemahaman siswa terhadap materi pembelajaran. Budiharjo (1996) menyebutkan dalam pemberian tugas terstruktur ini guru sebagai perencana, fasilitator, evaluator. Peran guru sebagai perencana adalah menentukan jenis tugas yang harus dikerjakan siswa sesuai dengan tujuan pembelajarannya. Sujono (1988) menjelaskan bahwa pemberian tugas terstruktur harus memperhatikan prinsip-prinsip. a) diberikan secara teratur. b) direncanakan sehingga waktu yang digunakan sesuai alokasi waktu pelajarannya. c) dapat memotivasi siswa sehingga proses belajar mengajar sesuai dengan tujuan belajar. d) tidak boleh dijadikan sebagai hukuman. e) hendaknya di review atau dikomentari guru, dan f) mampu mengatur serta mengetahui penguasaan siswa terhadap materi tugas dengan mengadakan ujian singkat.

Interaksi atau hubungan timbal balik antara guru dan siswa itu merupakan syarat utama bagi berlangsungnya proses belajar mengajar (Usman, 2000). Proses belajar mengajar dapat mengandung dua pengertian, yaitu rentetan kegiatan perencanaan oleh guru, pelaksanaan kegiatan sampai evaluasi program tindak lanjut (Suryabrata, 1997). Proses belajar mengajar Kimia meliputi kegiatan yang dilakukan guru mulai dari perencanaan, pelaksanaan kegiatan sampai evaluasi dan program tindak lanjut yang berlangsung dalam situasi edukatif untuk mencapai tujuan tertentu yaitu pembelajaran Kimia. Nana Syaodih (2004) menyebutkan "Hasil belajar atau achievement merupakan realisasi atau pemekaran dari kecakapakan-kecakapan potensial atau kapasitas yang dimiliki seseorang. Penguasaan hasil belajar oleh seseorang dapat dilihat dari perilakunya, baik perilaku dalam bentuk penguasaan pengetahuan, ketrampilan berpikir maupun ketrampilan motorik". Prestasi belajar yang dicapai oleh siswa dengan melibatkan seluruh potensi yang dimilikinya setelah siswa itu melakukan kegiatan belajar.

Penelitian yang dilakukan oleh oleh Sabriani (2016) dengan judul Pengaruh Pemberian Tugas Terstruktur dan Umpan Balik pada Pembelajaran Kooperatif Tipe STAD terhadap Hasil Belajar Kimia SiswaKelas XI SMA Negeri 3 Watampone menyimpulkan berdasarkan hasil analisis data, baik analisis deskriptif maupun analisis inferensial dan pembahasan, maka dapat disimpulkan bahwa tidak ada pengaruh pemberian tugas terstruktur pada pembelajaran kooperatif tipe STAD terhadap hasil belajar kimia siswa kelas XI SMA Negeri 3 Watampone. Tetapi berdasarkan nilai rata-rata hasil belajar yang diperoleh siswa, data menunjukkan bahwa nilai ratarata dari kelas yang diberikan tugas terstruktur dan umpan balik pada pembelajaran kooperatif tipe STAD lebih tinggi daripada kelas yang hanya diberikan pembelajaran kooperatif tipe STAD tanpa tugas terstruktur dan umpan balik. Penelitian yang dilakukan oleh Aldila \& Mulyanratna(2013) dengan judul Pengaruh Pemberian Tugas terstruktur Dalam Model Pembelajaran Kooperatif tipe STAD Terhadap Hasil Belajar Siswa pada Materi Fluida Statis di 
Kelas XI IPA SMA Negeri 1 Maospati menyimpulkan berdasarkan hasil analisis didapatkan simpulan bahwa metode pemberian tugas terstruktur berpengaruh positif dan berkorelasi kuat terhadap hasil belajar siswa.

\section{METODE PENELITIAN}

Penelitian ini adalah penelitian tindakan. Menurut Suharsimi Arikunto, dkk (2008) pada penelitian tindakan mempunyai empat tahapan yang lazim dilalui yaitu (1) perencanaan , (2) pelaksanaan, (3) pengamatan, (4) refleksi. Penelitian dilakukan di MAN 2 Sragen, Pedak Karangwaru Plupuh Sragen pada semester genap tahun pelajaran 2017/2018. Subyek penelitian ini adalah siswa kelas X IPA 3 yang terdiri dari 11 siswa laki-laki dan 29 siswa perempuan. Untuk mendapatkan data-data penelitian digunakan digunakan teknik pengumpulan data berupa tes, observasi dan diskusi Tes digunakan untuk mrndapatkan data tentang hasil belajar siswa. Observasi dipergunakan untuk mengumpulkan data tentang partisipasi siswa dalam proses pembelajaran. Diskusi digunakan sebagai refleksi hasil persiklus dalam penelitian tindakan kelas. Instrumen yang digunakan non tes dan tes. Non tes dengan menggunakan dokumendokumen berupa Silabus, RPP, Lembar kegiatan siswa yang meliputi lembar observasi pengolahan kombinasi metode diskusi kelompok dan penugasan terstruktur untuk mengamati proses pengelolaan pembelajaran dan Lembar observasi aktivitas siswa dan guru, untuk mengamati aktivitas siswa dan guru selama proses pembelajaran. Tes formatif digunakan untuk mengukur kemampuan pemahaman konsep kimia Tes formatif diberikan setiap akhir putaran dengan bentuk soal pilihan ganda.

Pada penelitian ini menggunakan teknik analisis deskriptif kualitatif, yaitu suatu metode penelitian yang bersifat menggambarkan kenyataan atau fakta sesuai dengan data yang diperoleh dengan tujuan untuk mengetahui prestasi belajar yang dicapai siswa juga untuk memperoleh respon siswa terhadap kegiatan pembelajaran serta aktivitas siswa selama proses pembelajaran. Untuk mengalisis tingkat keberhasilan atau persentase keberhasilan siswa setelah proses belajar mengajar setiap putarannya dilakukan dengan cara memberikan evaluasi berupa soal tes tertulis pada setiap akhir putaran. ketuntasan belajar yaitu secara perorangan dan secara klasikal. Berdasarkan petunjuk pelaksanaan belajar mengajar kurikulum 1994 (Depdikbud, 1994), yaitu seorang siswa telah tuntas belajar bila telah mencapai skor $65 \%$ atau nilai 65, dan kelas disebut tuntas belajar bila di kelas tersebut terdapat $85 \%$ yang telah mencapai daya serap lebih dari atau sama dengan $65 \%$. Peningkatan hasil belajar diamati dari peningkatan hasil belajar siswa pada siklus I dan siklus II.

\section{HASIL DAN PEMBAHASAN}

Hasil analisis data diperoleh berdasarkan hasil observasi terhadap kegiatan pembelajaran kombinasi metode diskusi kelompok dan penugasan terstruktur yang dilakukan dalam dua siklus. Pembelajaran pada siklus I terdiri dari dua pertemuan dengan materi yang berbeda pada setiap pertemuan. Pada pertemuan pertama, siswa belajar tentang perkembangan reaksi redoks dan penentuan bilangan oksidasi. Dalam pembelajaran siswa dibagi menjadi kelompok-kelompok kecil. Sebagai lanjutan pemahaman atas materi yang diberikan dalam diskusi siswa diberikan tugas terstruktur secara individu tentang penentuan bilangan oksidasi. Pada pertemuan kedua, siswa belajar tentang menentukan reaksi redoks, reduktor dan oksidator dengan media pembelajaran yang digunakan yaitu lembar kegiatan (LK) siswa. Sama halnya pada pertemuan kedua, setelah pembelajran selesai siswa diberi tugas terstruktu tentang menentukan reaksi redoks, reduktor dan oksidator secara individu. Kegiatan pembelajaran pada setiap pertemuan dilakukan berdasarkan tiga tahap pembelajaran,yaitu tahap pendahuluan, tahap inti,dan tahap penutup.

Kegiatan pembelajaran yang dilakukan pada tahap pendahuluan,meliputi (1) guru memberi salam untuk membuka pelajaran, (2) guru mengajak siswa berdoa untuk mengawali pembelajaran, (3) guru melakukan mengecek kehadiran siswa, (4) guru melakukan apersepsi (5) guru menyampaikan kompetensi yang akan dicapai dalam pembelajaran dan (6) guru 
memotivasi siswa dengan memberikan gambaran tentang manfaat mempelajari redoks dan tatanama senyawa dalam kehidupan sehari-hari. Selanjutnya kegiatan pembelajaran yang dilakukan pada tahap inti meliputi (1) Guru menyuruh siswa mengelompok sesuai kelompok yang sudah ditetapkan (2) Guru menyampaikan materi singkat tentang perkembangan redoks dan bilangan oksidasi (3) Guru membagikan LK pada setiap kelompok (4) Siswa mendiskusikan tugas kelompok pada LK (4) Guru mengamati keaktifan siswa pada setiap kelompok (5) Siswa mempresentasikan hasil diskusi kelompok (6) Guru mengamati dan menilai prsentasi siswa. Pada kegiatan penutup meliputi (1) Guru menyimpulkan hasil diskusi dan melakukan refleksi bersama siswa (2) Guru memberikan reward pada kelompok yang memiliki kinerja dan kerjasama yang baik. (3) Guru memberikan tugas terstruktur individu untuk penguatan materi yang baru disampaikan. (4) Guru menutup pelajaran dengan doa dan salam penutup.

Pembelajaran pada siklus II terdiri dari dua pertemuan dengan materi yang berbeda pada setiap pertemuan. Pada pertemuan pertama, siswa belajar tentang penerapan aturan tata nama senyawa anorganik dan organik sederhana menurut aturan IUPAC. Dalam pembelajaran siswa dibagi menjadi kelompok-kelompok kecil. Sebagai lanjutan pemahaman atas materi yang diberikan dalam diskusi siswa diberikan tugas terstruktur secara individu tentang penentuan tata nama senyawa sesuai aturan IUPAC. Pada pertemuan kedua, siswa belajar tentang menentukan nama beberapa senyawa sesuai aturan IUPAC dengan media pembelajaran yang digunakan yaitu lembar kegiatan (LK) siswa. Sama halnya pada pertemuan kedua, setelah pembelajran selesai siswa diberi tugas terstruktur tentang menentukan nama senyawa aturanIUPAC secara individu. Kegiatan pembelajaran pada setiap pertemuan dilakukan berdasarkan tiga tahap pembelajaran,yaitu tahap pendahuluan, tahap inti,dan tahap penutup.

Pada pertemuan pertama kegiatan pembelajaran yang dilakukan pada tahap pendahuluan, meliputi (1) guru memberi salam untuk membuka pelajaran, (2) guru mengajak siswa berdoa untuk mengawali pembelajaran, (3) guru melakukan mengecek kehadiran siswa, (4) guru melakukan apersepsi materi pertemuan pertama (5) guru menyampaikan kompetensi yang akan dicapai dalam pembelajaran dan (6) guru memotivasi siswa dengan memberikan gambaran tentang manfaat mempelajari redoks dan tatanama senyawa dalam kehidupan seharihari. Selanjutnya kegiatan pembelajaran yang dilakukan pada tahap inti meliputi (1) Guru menyuruh siswa mengelompok sesuai kelompok yang sudah ditetapkan (2) Guru menyampaikan materi singkat aturan tatanama senyawa organik dan an organikmenurut aturan IUPAC (3) Guru membagikan LK pada setiap kelompok (4) Siswa mendiskusikan tugas kelompok pada LK (4) Guru mengamati keaktifan siswa pada setiap kelompok (5) Siswa mempresentasikan hasil diskusi kelompok (6) Guru mengamati dan menilai prsentasi siswa. Pada kegiatan penutup meliputi (1) Guru menyimpulkan hasil diskusi dan melakukan refleksi bersama siswa (2) Guru memberikan reward pada kelompok yang memiliki kinerja dan kerjasama yang baik. (3) Guru memberikan tugas terstruktur individu untuk penguatan materi yang baru disampaikan. (4) Guru menutup pelajaran dengan doa dan salam penutup.

Untuk mengetahui keberhasilan metode yang digunakan pada setiap pertemuam dilakukan pengamatan keaktifan siswa. Untuk mengetahui tingkat keberhasilan prestasi belajar siswa setiap akhir putaran siklus dilakukan tes fomatif. Jadi ada dua kali tes formatif yang dilakukan. Berikut disajikan hasil tes formatif :

Table 1.Nilai Ulangan Harian Pada Siklus I

\begin{tabular}{|l|l|l|l|l|l|l|l|}
\hline \multirow{2}{*}{ No. Urut } & \multirow{2}{*}{ Nilai } & \multicolumn{2}{|l|}{ Keterangan } & \multirow{2}{*}{ No. Urut } & \multirow{2}{*}{ Nilai } & \multicolumn{2}{|l|}{ Keterangan } \\
\cline { 8 - 10 } & & T & TT & & & T & TT \\
\hline 1 & 80 & $\sqrt{ }$ & & 21 & 70 & $\sqrt{ }$ & \\
\hline 2 & 50 & & $\sqrt{ }$ & 22 & 60 & & $\sqrt{ }$ \\
\hline 3 & 80 & $\sqrt{ }$ & & 23 & 80 & $\sqrt{ }$ & \\
\hline 4 & 60 & $\sqrt{ }$ & & 24 & 80 & $\sqrt{ }$ & \\
\hline 5 & 60 & & $\sqrt{ }$ & 25 & 60 & & $\sqrt{ }$ \\
\hline
\end{tabular}




\begin{tabular}{|l|l|l|l|l|l|l|l|}
\hline 6 & 80 & $\sqrt{ }$ & & 26 & 80 & $\sqrt{ }$ & \\
\hline 7 & 70 & $\sqrt{ }$ & & 27 & 70 & $\sqrt{ }$ & \\
\hline 8 & 60 & & $\sqrt{ }$ & 28 & 80 & $\sqrt{ }$ & \\
\hline 9 & 80 & $\sqrt{ }$ & & 29 & 60 & & $\sqrt{ }$ \\
\hline 10 & 80 & $\sqrt{ }$ & & 30 & 80 & $\sqrt{ }$ & \\
\hline 11 & 60 & & $\sqrt{ }$ & 31 & 60 & $\sqrt{ }$ & \\
\hline 12 & 60 & & $\sqrt{ }$ & 32 & 60 & & $\sqrt{ }$ \\
\hline 13 & 80 & $\sqrt{ }$ & & 33 & 70 & $\sqrt{ }$ & \\
\hline 14 & 80 & $\sqrt{ }$ & & 34 & 60 & & $\sqrt{ }$ \\
\hline 15 & 60 & & $\sqrt{ }$ & 35 & 80 & $\sqrt{ }$ & \\
\hline 16 & 50 & & $\sqrt{ }$ & 36 & 70 & $\sqrt{ }$ & \\
\hline 17 & 70 & $\sqrt{ }$ & & 37 & 60 & & $\sqrt{ }$ \\
\hline 18 & 70 & $\sqrt{ }$ & & 38 & 70 & $\sqrt{ }$ & \\
\hline 19 & 70 & & & 39 & 80 & $\sqrt{ }$ & \\
\hline 20 & 80 & $\sqrt{7}$ & & 40 & 60 & & $\sqrt{ }$ \\
\hline \multicolumn{7}{|l|}{} \\
\hline
\end{tabular}

Keterangan:

$\mathrm{T}$

TT

Jumlah siswa yang tuntas

Jumlah siswa yang belum tuntas

Klasikal
: Tuntas

: Tidak Tuntas

$: 26$

$: 14$

: Belum tuntas

Tabel 2. Rekapitulasi Hasil Ulangan Harian Siswa pada Siklus I

\begin{tabular}{|l|l|l|}
\hline No & Uraian & Hasil Siklus I \\
\hline 1 & Nilai rata-rata ulangan Harian & 69,25 \\
2 & Jumlah siswa yang tuntas belajar & 26 \\
3 & Persentase ketuntasan belajar & $65 \%$ \\
\hline
\end{tabular}

Dari tabel di atas dapat dijelaskan bahwa dengan menerapkan kombinasi metode diskusi kelompok dengan penugasan terstruktur diperoleh nilai rata-rata prestasi belajar siswa adalah 68,75 dan ketuntasan belajar mencapai $65 \%$ atau ada 26 siswa dari 40 siswa sudah tuntas belajar. Hasil tersebut menunjukkan bahwa pada siklus pertama secara klasikal siswa belum tuntas belajar, karena siswa yang memperoleh nilai $\geq 65$ hanya sebesar $65 \%$ lebih kecil dari persentase ketuntasan yang dikehendaki yaitu sebesar $85 \%$. Hal ini disebabkan karena siswa masih banyak asing dengan motode pembelajaran yang baru diterapkan.

Table 3. Nilai Ulangan Harian Pada Siklus II

\begin{tabular}{|l|l|l|l|l|l|l|l|}
\hline \multirow{2}{*}{ No. Urut } & \multirow{2}{*}{ Nilai } & \multicolumn{2}{|l|}{ Keterangan } & \multirow{2}{*}{ No. Urut } & \multirow{2}{*}{ Nilai } & \multicolumn{2}{|l|}{ Keterangan } \\
\cline { 7 - 9 } & & T & TT & & & T & TT \\
\hline 1 & 80 & $\sqrt{ }$ & & 21 & 80 & & \\
\hline 2 & 70 & $\sqrt{ }$ & & 22 & 60 & $\sqrt{ }$ & \\
\hline 3 & 80 & $\sqrt{ }$ & & 23 & 90 & & \\
\hline 4 & 60 & & $\sqrt{ }$ & 24 & 90 & & \\
\hline 5 & 80 & $\sqrt{n n n n n y y y}$ & & 25 & 80 & & \\
\hline 6 & 80 & $\sqrt{ }$ & & 26 & 80 & & \\
\hline 7 & 80 & $\sqrt{ }$ & & 27 & 80 & & \\
\hline
\end{tabular}




\begin{tabular}{|l|l|l|l|l|l|l|l|}
\hline 8 & 80 & & & 28 & 80 & & \\
\hline 9 & 80 & & & 29 & 80 & & \\
\hline 10 & 80 & $\sqrt{ }$ & & 30 & 80 & & \\
\hline 11 & 85 & $\sqrt{ }$ & & 31 & 60 & $\sqrt{ }$ & \\
\hline 12 & 80 & $\sqrt{ }$ & & 32 & 80 & & \\
\hline 13 & 85 & $\sqrt{ }$ & & 33 & 70 & & \\
\hline 14 & 80 & $\sqrt{ }$ & & 34 & 70 & & \\
\hline 15 & 60 & $\sqrt{ }$ & $\sqrt{ }$ & 35 & 90 & & \\
\hline 16 & 60 & $\sqrt{ }$ & $\sqrt{ }$ & 36 & 80 & & \\
\hline 17 & 80 & $\sqrt{ }$ & & 37 & 70 & & \\
\hline 18 & 70 & $\sqrt{ }$ & & 38 & 80 & & \\
\hline 19 & 80 & $\sqrt{ }$ & & 39 & 90 & & \\
\hline 20 & 80 & $\sqrt{ }$ & & 40 & 80 & & \\
\hline Jumlah & 1530 & 17 & 3 & Jumlah & 1570 & 18 & 2 \\
\hline $\begin{array}{l}\text { Jumlah Skor 3100 } \\
\text { Jumlah Skor Mask. Ideal } 4000 \\
\% \text { Skor Tercapai } 77,50\end{array}$ \\
\hline
\end{tabular}

Keterangan:

$\mathrm{T}$

TT

Jumlah siswa yang tuntas

Jumlah siswa yang belum tuntas

Klasikal
: Tuntas

: Tidak Tuntas

$: 40$

$: 5$

: Tuntas

Tabel 4. Hasil Ulanagan Harian Siswa pada Siklus II

\begin{tabular}{|l|l|l|}
\hline No & Uraian & Hasil Siklus II \\
\hline 1 & Nilai rata-rata Ulangan Harian & 77,50 \\
2 & Jumlah siswa yang tuntas belajar & 40 \\
3 & Persentase ketuntasan belajar & $87,5 \%$ \\
\hline
\end{tabular}

Dari tabel di atas diperoleh nilai rata-rata prestasi belajar siswa adalah 77,50 dan ketuntasan belajar mencapa 87,5\% atau ada 35 siswa dari 40 siswa sudah tuntas belajar. Hasil ini menunjukkan bahwa pada siklus II ini ketuntasan belajar secara klasikal telah mengalami peningkatan sedikit lebih baik dari siklus I. Berdasarkan petunjuk pelaksanaan belajar mengajar kurikulum 1994 (Depdikbud, 1994), yaitu seorang siswa telah tuntas belajar bila telah mencapai skor $65 \%$ atau nilai 65 , dan kelas disebut tuntas belajar bila di kelas tersebut terdapat $85 \%$ yang telah mencapai daya serap lebih dari atau sama dengan 65\%. Dengan demikian pada siklus II secara klasikal pembelajaran sudah tuntas. Adanya peningkatan hasil belajar siswa ini karena siswa sudah mulai akrab metode pembelajaran yang diterapkan oleh guru. Disamping itu kemampuan guru dalam pengelolaan proses belajar mengajar semakin mantap sehingga hasilnya pun prestasi siswa semakin meningkat.

\section{Pembahasan}

Dari data hasil siklus I dapat diketahui bahwa hasil ketuntasan belajar siswa adalah 65 $\%$, hasil ini lebih baik dibanding dengan kondisi awal sebelum penerapan ini dilakukan. Dari data hasil penelitian pada siklus II dapat diketahui bahwa hasil ketuntasan belajar siswa adalah $87,5 \%$. Hasil iini menunjukkan peningkatan hasil bejara siswa baik dari kondisi awal maupun dengan siklus Untuk memperjelas keberhasilan pembelajaran setelah diadakan tindakan pada siklus I dan II maka dapat dilihat data komparatif sebagai mana tabel 5 berikut ini, 
Tabel 5. Data Komparatif keadaan awal, siklus I dan siklus II

\begin{tabular}{|c|c|c|c|c|c|}
\hline \multirow[t]{2}{*}{ No } & \multirow{2}{*}{$\begin{array}{l}\text { No Absen } \\
\text { Siswa }\end{array}$} & \multicolumn{3}{|l|}{ Prestasi Belajar } & \multirow[t]{2}{*}{ Keterangan } \\
\hline & & Kondisi Awal & Siklus I & Siklus II & \\
\hline 1 & 1 & 50 & 80 & 80 & $\mathrm{~T}$ \\
\hline 2 & 2 & 50 & 50 & 70 & $\mathrm{~T}$ \\
\hline 3 & 3 & 40 & 80 & 80 & $\mathrm{~T}$ \\
\hline 4 & 4 & 60 & 60 & 60 & TT \\
\hline 5 & 5 & 70 & 60 & 80 & $\mathrm{~T}$ \\
\hline 6 & 6 & 50 & 80 & 80 & $\mathrm{~T}$ \\
\hline 7 & 7 & 60 & 70 & 80 & $\mathrm{~T}$ \\
\hline 8 & 8 & 60 & 60 & 80 & $\mathrm{~T}$ \\
\hline 9 & 9 & 50 & 80 & 80 & $\mathrm{~T}$ \\
\hline 10 & 10 & 65 & 80 & 80 & $\mathrm{~T}$ \\
\hline 11 & 11 & 50 & 60 & 85 & $\mathrm{~T}$ \\
\hline 12 & 12 & 45 & 60 & 80 & $\mathrm{~T}$ \\
\hline 13 & 13 & 75 & 80 & 85 & $\mathrm{~T}$ \\
\hline 14 & 14 & 80 & 80 & 80 & $\mathrm{~T}$ \\
\hline 15 & 15 & 50 & 60 & 60 & TT \\
\hline 16 & 16 & 50 & 50 & 60 & TT \\
\hline 17 & 17 & 50 & 70 & 80 & $\mathrm{~T}$ \\
\hline 18 & 18 & 55 & 70 & 70 & $\mathrm{~T}$ \\
\hline 19 & 19 & 50 & 70 & 80 & $\mathrm{~T}$ \\
\hline 20 & 20 & 50 & 80 & 80 & $\mathrm{~T}$ \\
\hline 21 & 21 & 55 & 70 & 80 & $\mathrm{~T}$ \\
\hline 22 & 22 & 40 & 60 & 60 & TT \\
\hline 23 & 23 & 75 & 80 & 90 & $\mathrm{~T}$ \\
\hline 24 & 24 & 50 & 80 & 90 & $\mathrm{~T}$ \\
\hline 25 & 25 & \begin{tabular}{|l}
70 \\
\end{tabular} & 60 & 80 & $\mathrm{~T}$ \\
\hline 26 & 26 & 75 & 80 & 80 & $\mathrm{~T}$ \\
\hline 27 & 27 & \begin{tabular}{|l}
70 \\
\end{tabular} & 70 & 80 & $\mathrm{~T}$ \\
\hline 28 & 28 & 65 & 80 & 80 & $\mathrm{~T}$ \\
\hline 29 & 29 & 65 & 60 & 80 & $\mathrm{~T}$ \\
\hline 30 & 30 & 65 & 80 & 80 & $\mathrm{~T}$ \\
\hline 31 & 31 & 50 & 60 & 60 & TT \\
\hline 32 & 32 & 55 & 60 & 80 & $\mathrm{~T}$ \\
\hline 33 & 33 & 50 & 70 & 70 & $\mathrm{~T}$ \\
\hline 34 & 34 & 50 & 60 & 70 & $\mathrm{~T}$ \\
\hline 35 & 35 & 60 & 80 & 90 & $\mathrm{~T}$ \\
\hline 36 & 36 & 50 & 70 & 80 & $\mathrm{~T}$ \\
\hline 37 & 37 & 60 & 60 & 70 & $\mathrm{~T}$ \\
\hline 38 & 38 & 65 & 70 & 80 & $\mathrm{~T}$ \\
\hline 39 & 39 & 70 & 80 & 90 & $\mathrm{~T}$ \\
\hline 40 & 40 & 60 & 60 & 80 & $\mathrm{~T}$ \\
\hline
\end{tabular}

Keterangan:

$\mathrm{T}$

TT
: Tuntas

: Tidak Tuntas

Melalui hasil peneilitian ini menunjukkan bahwa metode diskusi kelompok dan penugasan terstruktur memiliki dampak positif dalam meningkatkan motivasi dan prestasi belajar siswa. Hal ini dapat dilihat dari semakin mantapnya pemahaman siswa terhadap materi yang disampaikan guru (ketuntasan belajar meningkat dari sklus I dan II, ) yaitu masing-masing $65 \%$ dan 87,5\%, . Pada siklus II ketuntasan belajar siswa secara klasikal telah tercapai. 
Peningkatan motivasi belajar siswa dalam diskusi kelompok sejalan dengan pendapat Huda (2014) yang menyatakan salah satu asumsi yang mendasari pengembangan pembelajaran kelompok (cooperative learning) adalah bahwa sinergi yang muncul melalui kerja sama akan meningkatkan motivasi yang jauh lebih besar dari pada melalui lingkungan kompetitif individual. Sedangkan untuk ketuntasan belajar sesuai dengan Trianto (2010) selama bekerja dalam kelompok, tugas anggota kelompok adalah mencapai ketuntasan materi yang disajikan oleh guru dan saling membantu teman sekelompoknya untuk mencapai ketuntasan belajar. Sedangkan penugasan terstruktur dapat memperdalam dan menguatkan pemahaman materi yang diberikan oleh guru seperti yang disampaikan oleh Sagala (2010) tugas dapat lebih meyakinkan tentang apa yang dipelajari dari guru, lebih memperdalam, memperkaya, atau memperluas wawasan tentang apa yang dipelajari. Menurut Restiyah (1998) dengan melaksanakan tugas peserta didik akan aktif belajar, dan merasa terangsang untuk meningkatkan belajar yang lebih baik, memupuk inisiatif dan berani bertanggung jawab sendiri. Penelitian ini juga didukung oleh beberapa penelitian yang telah dilakukan sebelumnya yang relevan yaitu Sabriani (2016) dengan hasil penelitian terjadi peningkatan nilai rata-rata siswa yang diberikan tugas terstruktur pada pembelajaran dengan metode STAD pada siswa kelas XI SMA 3 Watampone. Penelitian yang dilakukan (Aldila \& Mulyanratna, 2013) didapatkan simpulan bahwa metode pemberian tugas terstruktur berpengaruh positif dan berkorelasi kuat terhadap hasil belajar siswa XI IPA SMA Negeri 1 Maospati.

\section{KESIMPULAN}

Penerapan Kombinasi Metode Diskusi Kelompok dan Penugasan Terstruktur pada siswa kelas X IPA3 MAN 2 Sragen dapat meningkatkan hasil belajar kimia pada materi reaksi reduksi dan oksidasi menggunakan konsep bilangan oksidasi unsur. Pada pratindakan rataa-rata prestsi belajar siswa 57,75. Pasca tindakan pada siklus I diperoleh nilai rata-rata 69,25 dengan ketuntasan klasikal 65\%. Pada siklus II diperoleh nilai rata-rata 77,5 dengan ketuntasan klasikal $87,5 \%$. Berdasarkan hasil penelitian dapat disimpulkan bahwa prestasi belajar siswa meningkat dengan diterapkannnya kombinasi metode diskusi kelompok dan penugasan terstruktur. Hal ini bisa dilihat dari peningkatan rata-rata prestasi belajar dari pratindakan ke siklus I, dari siklus I ke siklus II.

\section{DAFTAR PUSTAKA}

Aldila, Herman dan Madewi Mulyanratna. (2013). Pengaruh Pemberian Tugas terstruktur Dalam Model Pembelajaran Kooperatif tipe STAD Terhadap Hasil Belajar Siswa pada Materi Fluida Statis di Kelas XI IPA SMA Negeri 1 Maospati . Jurnal Inovasi Pendidikan Fisika. Vol. 2 No. 2 hal 49 - 54

Arikunto, Suharsimi,dkk. (2008). Penelitian Tindakan Kelas. Jakarta: Bumi Aksara.

Budiharjo. L, dkk (1996). Mengajar di Perguruan Tinggi. Jakarat : Dikti

Departemen Pendidikan dan Kebudayaan. (1994). Petunjuk Pelaksanaan Proses Belajar Mengajar, Jakarta. Balai Pustaka.

Departemen Pendidikan dan Kebudayaan. (1994). Didaktik dan Metode Umum, Jakarta. Departemen Pendidikan dan Kebudayaan.

Depdiknas. (2005). Landasan Teori Dalam Pengembangan Metode Pengajaran. Depdiknas

Dimyati, Moh dan Moedjiono. (1993). Strategi Belajar Mengajar. Jakarta : Dirjen Dikti

Direktorat Pembinaan SMA Dikdasmen Kemendikbud, 2017. Panduan Pengembangan Pembelajaran Aktif. Jakarta : Kemendikbud

Djamarah, Syaiful Bahri, dan Zain Aswan. (2006). Strategi Belajar Mengajar Edisi Revisi. Jakarta: Rineksa Cipta.

Devi, Poppy K. (2016). Modul Guru Pembelajar Mata Pelajaran Kimia Sekolah Menengah Atas. Jakarta: Kemendikbud.

Huda, Miftahul. (2014). Model-model Pengajaran dan Pembelajaran Isu-isu Metodis dan Paradigmatis. Yogyakarta : Pustaka Pelajar 
Moh. Uzer Usman. (2001). Menjadi Guru Profesional. Bandung: Remaja Rosdakarya.

Nana Syaodih Sukmadinta. (2004). Landasan Psikologi Proses pendidikan. Bandung: Remaja Rosdakarya.

Restiyah NK. (1998). Strategi Belajar Mengajar. Jakarta: Rineka Cipta

Sagala, Syaiful. (2009). Konsep Dan Makna Pembelajaran. Bandung: Alfabeta

Sitti Sabriani. (2016). Pengaruh Pemberian Tugas Terstruktur dan Umpan Balik pada Pembelajaran Kooperatif Tipe STAD terhadap Hasil Belajar Kimia Siswa Kelas XI SMA Negeri 3 Watampone. Jurnal Chemica Vol. 17 No. 1 hal $50-57$

Sujono. (1988). Pengajaran Matematika Untuk Sekolah Menengah. Jakarta : Dikti

Suryosubroto, B. (1997). Proses Belajar Mengajar di Sekolah. Jakarta: PT. Rineksa Cipta. Trianto. (2010). Mendesain Model Pembelajaran Inovatif-Progresif. Jakarta: Kencana Usman, Moh. Uzer. (2001). Menjadi Guru Profesional. Bandung: Remaja Rosdakarya. 